\title{
The Role of Mediating Effects of User Satisfaction and Behavioural Intention on the Influence of the Electronic Tax System on Tax Compliance Behaviour: An application of Bootstrapping Technique
}

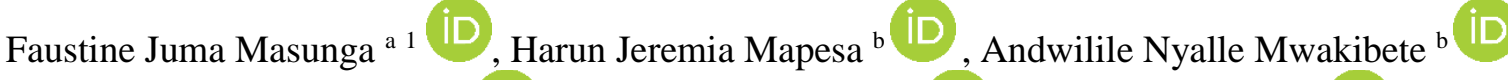 \\ Moshi James Derefa ${ }^{\text {b }}$, Jema Edmund Myava ${ }^{\text {b }}$ iD Joseph Simon Kiria ${ }^{\text {b }}$ iD
}

\author{
${ }^{a}$ National Institute of Transport, P.O. BOX 705, Dar es Salaam, Tanzania \\ ${ }^{b}$ Mzumbe University, P.O. BOX 1, Morogoro, Tanzania
}

\begin{abstract}
APA Citation:
Masunga, F.J., Mapesa, H.J., Mwakibete, A.N., Derefa, M.J., Myava, J.E. \& Kiria, J.S. (2021). The role of mediating effects of user satisfaction and behavioural intention on the influence of the electronic tax system on tax compliance behaviour: an application of bootstrapping technique. TIJAB (The International Journal of Applied Business), 5(2), 137-154.

Submission Date: 17/08/2021

Acceptance Date: 29/10/2021

\section{Abstract}

The purpose of this study was based on the role of mediating effects of user satisfaction and behavioural intention on the influence of the e-tax system on tax compliance behaviour. A mixed-methods approach (sequential explanatory design) was applied where the qualitative findings were used to supplement the results from the quantitative findings. A PLS-SEM technique with SmartPLS 3 was used to analyse data quantitatively while the qualitative data were analysed using thematic analysis. The results revealed that behavioural intention mediates only the relationship between information quality and tax compliance behaviour. When applying multiple mediators, the findings unveiled that service quality and system quality have a significant positive indirect effect on tax compliance behaviour.
\end{abstract}

Keywords: e-tax system; mediating effects; tax compliance behaviour

This is an open access article under the $\underline{C C B Y-N C-S A \text { license. }}$

\section{Introduction}

The mediation paradigm has been increasingly needed in contemporary literature and research endeavours (Bullock et al., 2010; Mathieu \& Taylor, 2006). Mediator variables are fundamental of social science and business research and are indispensable tools to develop a better scientific thought of the contrivances that interfere with the association between the explanatory and outcome variables (Pieters, 2017; Rucker et al., 2011). Mediation effects on the other hand are the standard method and procedure to test theories to apprehend the causal relationship (Baron \& Kenny, 1986; MacKinnon \& Luecken,

\footnotetext{
${ }^{1}$ Corresponding author.

E-mail address: faustine.masunga@nit.ac.tz
} 
2008; Preacher \& Hayes, 2004). Conceptually and theoretically, a mediator is the one that determines the nature of the relationship and explains why the association between the explanatory variable and endogenous variable subsists (Hair et al., 2017).

Despite the increasing emphasis by hodgepodge studies on mediation analysis, studies have sustained to use primaeval methods which reported to have flaws in explaining only the causal approach and failed to show the mediated effect itself (Baron \& Kenny, 1986; Green et al., 2016; Hayes \& Scharkow, 2013). Correspondingly, modern studies have remained in the trend of using the Sobel Test to evaluate the mediation with partial, inadequate, and ineffective reporting of the results. In evaluating mediation, this study employs a bootstrapping technique that overcomes the weaknesses of the Sobel Test.

Bootstrapping techniques conceptualize the weaknesses of the previous studies and provide a clear understanding of the misapprehensions on mediation analysis and inform future studies on appropriate ways of testing mediation analysis (Zhao, Lynch, \& Chen, 2010). Apart from using bootstrapping to evaluate the role of mediation, this study involved two mediator variables (behavioural intention and user satisfaction) to show how the variables influence tax compliance behaviour compared to a single mediator variable. In multiple mediations, a researcher may opt to run a simple mediation with each mediator variable separately or may decide to combine the mediator variables simultaneously (Hair et al., 2017; Memon et al., 2018). This study estimated the mediation effects by evaluating a single mediator (either user satisfaction or behavioural intention) and combining the two mediator variables (user satisfaction and behavioural intention) simultaneously.

\section{Literature Review}

In reviewing the literature, both perspectives were studied that is the theoretical literature review and the empirical literature review.

\subsection{Theoretical Perspective}

Behavioural Intention is the degree to which an individual has developed conscious plans to perform or not to engage in a particular behaviour (Davis \& Venkatesh,1996). It is inspirational or motivating factors that influence a given behaviour. As the intention to perform the behaviour increases, it is more apparent that the behaviour will be performed (Sondakh, 2017). User Satisfaction, on the other hand, is the degree of an effective interface between an information system and the users of the system (DeLone \& McLean, 2003). User satisfaction is measured through; effectiveness of the system, the level of satisfaction, efficiency of the system, and adequacy of the system (Delone \&McLean, 2003; Lee, 2010: Teo et al., 2008). This study utilized the information system success model (The IS Success Model), the Technology Acceptance Model (TAM), and the Theory of Planned Behaviour (TPB). The TPB dictates that an individual's behaviour in society is influenced by certain factors that are developed and originate from a particular reason but emerge from a planned behaviour (Benk et al., 2011). This theory associates a person's beliefs and the behaviour that explains, the attitude, personal beliefs on a particular behaviour, and perceived behavioural control on a person's behavioural intention and the actual behaviour (Chen \& Yang, 2019). Three factors are explained under TPB which are subject norms, perceived behaviour, and social influence (behavioural attitude).

TAM on the other hand emphasizes two variables; Perceived Usefulness (PU) and Perceived Ease of Use (PEU). Perceived Usefulness is defined as the potential user's subjective possibility that the use of a certain system (e-tax system) could improve his/her action. Perceived Ease of Use refers to the degree to which the possible user expects the target system to be easy. The belief of the person towards a system may be subjective by other factors referred to as external variables. TAM is the most used model in predicting information technology adoption and acceptance (Monica \& Makokha, 2017). The 
IS success model provides a guideline on how the e-tax system depends on the purposes of the users and if the system enables the users to achieve the objectives of accepting and using the system (Chen et al., 2015). It measures the system quality, information quality, service quality, user intention, and user satisfaction on the system.

\subsection{Empirical Perspective}

Behavioural Intention to use the e-tax system being a mediating variable for this study, explained more by the attitude towards the e-tax system (perceived ease of use and perceived usefulness) as the prospect that individuals will employ the e-tax system when are ease or improve their performance. Behavioural intention to use the e-tax system plays a great role in actual behaviour (Davis \& Venkatesh, 1996). Perceived ease of use and perceived usefulness affect behavioural intention towards the use of the electronic tax system which impacts tax compliance behaviour (Li et., 2012). Behavioural intention to use the e-tax system is expected to influence the direct effect from perceived usefulness and perceived ease of use to actual behaviour (Budu et al., 2018).

Sondakh (2017) assessed the relationship of the e-tax service system and taxpayers' behavioural intention to accept the use of the system in Indonesia on actual behaviour. Data were analyzed using Structural Equation Modeling (SEM). The study tested two constructs that are perceived usefulness and perceived ease of use on behavioural intention to accept the e-tax service system and the actual behaviour. The findings affirmed that both perceived ease of use and perceived usefulness had a significant relationship on behavioural intention to use electronic tax service systems and the actual behaviour. That means the relationships between attitude towards the e-tax system (perceived ease of use and perceived usefulness) and tax compliance behaviour (actual behaviour) is mediated by behavioural intention. However, this study failed to indicate how behavioural intention mediates the effects of the perceived ease of use and perceived usefulness on actual behaviour.

Confirming for the theory if there is an association between attitude towards the electronic tax system variables (perceived ease of use, perceived usefulness) and tax compliance behaviour, behavioural intention explained these relationships. Kimathi \& Zhang (2019) examined the relationship between citizens' acceptance and use of e-tax filing and payment systems through behavioural intention to use the system in Tanzania and tax compliance behaviour employing SEM techniques in data analysis. Variables like system quality, perceived security, social influence, and perceived behavioural control were used as the constructs to test the relationship. The study integrated the Technology Acceptance Model and Theory of Planned Behaviour to explain the factors motivating the acceptance of electronic tax filing and payment systems (ETFPS).

The results indicated that perceived usefulness, perceived ease of use perceived security, system quality, and facilitating condition were statistically significant mediated by behavioural intention to use the electronic tax filing payment system on actual behaviour. Consistent findings were achieved by Rana et al. (2012) who confirmed that the relationships between perceived ease of use, perceived usefulness on actual behaviour is mediated by behavioural intention. That is, the significant results of attitude towards the e-filing on tax compliance are mediated by behavioural intention. Theoretically, there is a relationship between e-filing and tax compliance, but knowing how this relationship works; behavioural intention translates this relationship into actual behaviour (tax compliance). Impliedly, behavioural intention to use the system reveals the actual use of electronic filing. Budu et al.(2018) claimed that behavioural intention plays a limited mediating role in the association between perceived usefulness and electronic learning in the learning context. In social science research, user satisfaction can be used as a mediator to explain the relationship between the quality of the system and the actual benefit (Wahyudi 
et al., 2017). Ramayasa (2015) unveils that, the relationship between system quality and information quality on actual behaviour is mediated by user satisfaction.

The study by Hsu et al. (2015) on the aspects influencing electronic tax filing on user satisfaction showed an insignificant effect on user satisfaction. The study further affirmed that higher information quality (IQ) affects the perceived usefulness of the system (Quality, 2016). About service quality (SEVQ); the study indicated that better service quality improves the perception of user satisfaction (Floropoulos et al., 2010). Hyung (2016) assessed the effect of system quality on the execution of electronic tax invoices on user satisfaction. The study made use of the Information System Success Theory (IS Success Model). The results revealed that system quality has a positive effect on user satisfaction. The findings are ambivalence with that of Tsai et al. (2015); Monem et al. (2013); Kassim et al. (2012); Almutairi \& Subramanian (2005); Rai et al. (2002) which advocate that the quality of information from the system has a significant effect on user satisfaction and actual behaviour. If taxpayers who are the users of the information believe that the information delivered from the system has the required quality, taxpayers feel gratified and this impacts tax compliance behaviour. Extant empirical studies also show that if taxpayers are satisfied with the services provided by the system then; taxpayers would improve tax compliance behaviour (Ariyanto et al., 2020; Umar et al., 2019; Alabede et al., 2011).

A study by Mohammadi (2015) on users' perspectives on e-learning integrating both IS Success Model and Technology Acceptance Model in Iran. The study intended to explore the effects of quality features, perceived ease of use, perceived usefulness on users' intentions and satisfaction along with the mediating effect of usability towards the use of electronic learning. Data were collected through a survey and analyzed using structural equation modelling (SEM). The findings indicated that user satisfaction and intention to use both affect users' actual use positively. The findings further affirmed that system quality, information quality, and service quality positively affect users' actual use through behavioural intention and user satisfaction. Similar results were achieved by Hassanzadeh et al. (2012) in the context of e-learning that, if users of the system believe the system is easy, useful, has the required quality and the information received is from a trusted source, it increases the gratification of the users and creates consistent behavioural intention to continue using the system.

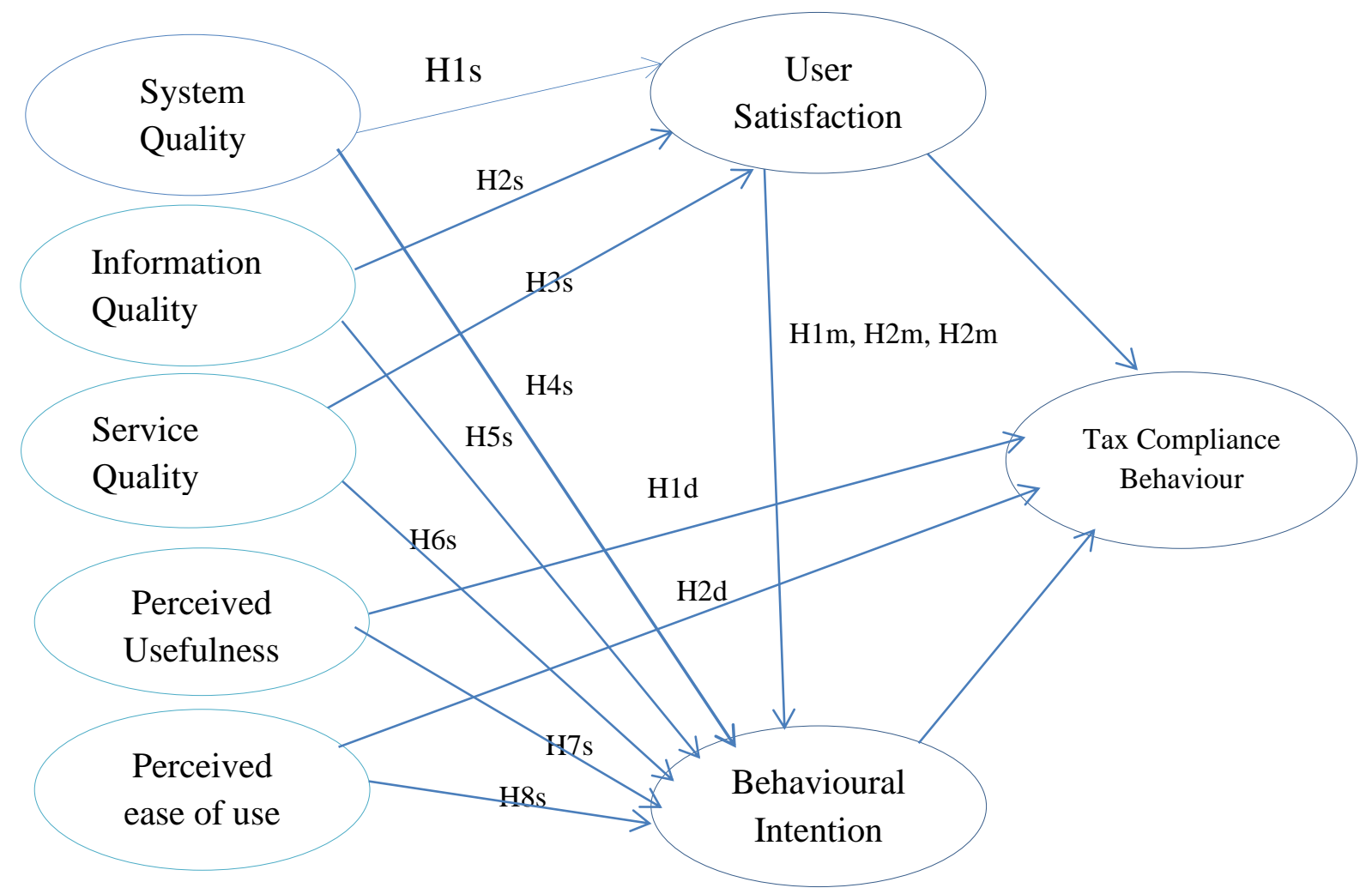


Figure 1. Conceptual model of the study

The following are the formulated hypotheses:

H1s: User satisfaction mediates the relationship between system quality and tax compliance behaviour

$\mathrm{H} 2 \mathrm{~s}$ : The relationship between information quality and tax compliance behaviour is mediated by user satisfaction.

H3s: The effect of service quality on tax compliance behaviour is mediated by user satisfaction.

$\mathrm{H} 4 \mathrm{~s}$ : The effect of system quality on tax compliance behaviour is mediated by behavioural intention

H5s: Behavioural intention mediates the relationship between information quality and tax compliance behaviour.

H6s: The influence of service quality on tax compliance behaviour is mediated by behavioural intention.

$\mathrm{H} 7 \mathrm{~s}$ : The influence of perceived usefulness on tax compliance behaviour is mediated by behavioural intention.

H8s: The influence of perceived ease of use on tax compliance behaviour is mediated by behavioural intention.

H1m: The effect of service quality and tax compliance behaviour is mediated by both user satisfaction and behavioural intention.

$\mathrm{H} 2 \mathrm{~m}$ : User satisfaction and behavioural intention mediate the effect between system quality and tax compliance behaviour.

$\mathrm{H} 3 \mathrm{~m}$ : User satisfaction and behavioural intention mediate the relationship between information quality and tax compliance behaviour.

H1d: Perceived usefulness has a direct effect on tax compliance behaviour

$\mathrm{H} 2 \mathrm{~d}$ : Perceived ease of use has a direct influence on tax compliance behaviour

(S: stands for single mediator and M: denotes multiple mediators: D signifies the direct effect).

\section{Method}

This study used mixed-methods (a sequential explanatory design that is, a quantitative study in the first phase followed by a qualitative study in the second phase. The essence of mixing quantitative and qualitative methods was to supplement each other and offer a comprehensive representation of the research problem (Kiria, 2017; Teddlie, 2007). The use of a mixed-methods strategy assists to explore issues that could not be possible when the study used either the methods (quantitative or qualitative separately). This study opted for a semi-structured interview that assisted a researcher to ask questions to gain more insight and trends that could not be informed through the use of a semi-structured questionnaire alone. The use of a mixed-methods strategy also maximizes the likelihood of obtaining great information that increases the credibility of results and provides the foundation for triangulation between different sources of data (Teddlie, 2007; Wisdom \& Creswell, 2013).

The emerging issues obtained from the quantitative analysis besides, motivated the researcher to use the mixed methods (sequential explanatory) strategy to answer the why in the qualitative method. In analyzing data quantitatively, the questionnaires were prepared in Likert scale items (with 1, 2, 3 ranging from very strongly disagree to disagree consecutively and 5, 6,7 ranged from agreeing to very strongly agree serially) and the middle number four (4) represented not sure or unclear. 
The findings from the data analyzed quantitatively showed that the mean values of tax compliance behaviour indicators (easy filing, easy payment, and due date payment) fall within the range of 3.265, 3.837, and 3.856 (Appendix 1). This means taxpayers were in suspicion concerning the success of the e-tax system in making easily filing their tax returns, due date payment of taxes, and easy payment of taxes. So to gain rich understandings (explanations), the researchers had to opt for the qualitative study. Data from 313 large taxpayers were analysed quantitatively using Bootstrapping Structural Equation Modeling (BSEM) with SmartPLS3 as software to confirm for theoretical measurement. The basis of selecting large taxpayers as the unit of analysis is manifold: First, any inception of the new electronic system is piloted to large taxpayers. Second, large taxpayers present many tax compliance risks and always strive to minimize their tax liabilities. Third, large taxpayers have complex business volumes and many transactions that require a system for keeping their records.

Therefore, it was apparent to use this group to evaluate the mediating effect knowing that many of them have embarked into the use of the e-tax system since 2001. On the other hand, the justification of applying PLS-SEM is twofold; firstly, the application of PLS-SEM was also required to gratify the intention of assessing the coefficient of determinations and confirm the relevant theory used in this study as suggested by Hair et al. (2019). The last reason that inspired the use of PLS-SEM is the convolution and complexity of the model. This study involved the test of mediator analysis and the direct and indirect effects in which PLS-SEM is capable of evaluating the multiple relationships (Hair et al., 2017).

A sample of 313 large taxpayers for this study was obtained using a stratified random sampling technique. According to URT (2017), large taxpayers are estranged into three sectors that are manufacturing and associated services, extractive and interrelated services and service sector (financial and telecommunication sector). During data collection, there were 468 large taxpayers (132 manufacturing and related services, 130 extractive and related services and 206 service sector).

A researcher took seventy per cent of 468 that formed 327 study participants. Of 327 questionnaires distributed, only 313 (96 per cent) were reverted and analysed. The sample size of 313 large taxpayers for quantitative met the requirement of the minimum sample size for PLS-SEM and that of the statistical power of seventy per cent (70\%) (Hair et al., 2017). The proportionate stratified random sampling of the three strata was involved to confirm each member in the stratum has an equal chance of being selected.

For example, the proportionate sample size for the service sector given the number of the study population in that sector was $(327 / 468 \times 206)=144$, extractive and the related services $(327 / 468 \times 130)$ $=91$ and manufacturing and the related service $(327 / 468 \times 132)=92$. After identifying the required sample size in each stratum, the last procedure was to use a random fishbowl method to select randomly select the study participant. This method is used when there is a complete list of the population being studied (Gitawaty, Tarbiyah, \& Training, 2010).

Grounded in the qualitative study, this study employed six (6) interviews to complement and support the quantitative results. Data from the qualitative study were analysed thematically with MAXQDA 2020. There are no definite processes in determining sample size in the qualitative study. Sample size in the qualitative method depends on what the researcher entails to know, what expects to achieve, the resources to commence the study, the practicality of data, and the trustworthiness and validity of the results (Hamid, 2013). For this study, specific consideration was taken to confirm a sample proposed is representative based on individual decisions to select respondents that finest suit the research question under the problem of analysis. The interviewees were taken from the three sectors of manufacturing, extractive, and service sector to make the sample representative.

There were two factors considered to be imperative before choosing interviewees for qualitative data. The first factor was to understand the key users of the electronic tax system. To avoid prejudice of including participants who are not acquainted with the use of the e-tax system, the researcher obtained 
information from Tanzania Revenue Authority (TRA) regarding the predominant users who have undertaken biometric fingerprint registration for using the e-tax system. The second factor, the period users (managers or directors) have been using the e-tax system was essential to understand the familiarity of users of the e-tax system. The period in which taxpayers have been using the e-tax system was mirrored through Taxpayer Identification Number (TIN) and the time the system has been installed. Because the results of qualitative data do not require generalization, six (6) respondents for the qualitative study were purposely selected based on the two aspects stated above.

As contended by hodgepodge studies that sample size for qualitative studies is not a fundamental concern as it does not necessitate a researcher to make a statistical generalization of the findings achieved (Onwuegbuzie and Leech, 2005). The interviewees for qualitative data were chosen both purposively and based on convenience (grounded on the proper use of the e-tax system for an anticipated period and approachability by the researcher). The chosen managers signifying their businesses or organisations were disseminated as two interviewees from the manufacturing sector, two from the extractive sector and two from the service sector. The essence is to explore detailed information including the perception, views on the e-tax system usage and the reasons for the results which showed insignificances during quantitative data analysis.

During the qualitative analysis, themes were established from the replies of the interviewees linked with the results from the quantitative study. Taxpayers were interviewed to offer their perceptions and opinions about the attitude toward the e-tax system grounding on the usefulness of the system and ease of use of the e-tax system, their responses were mixed. The responses from the interviewed taxpayers provided a real picture of the findings obtained from the quantitative study. The results from the qualitative study supplemented that of the quantitative findings by providing an insight into the reasons for unsupported influences.

\section{Results}

\subsection{Mediation Analysis}

In testing mediation, bootstrapping technique of PLS-SEM was used to evaluate for mediation than Sobel Test based on the fact that PLS-SEM is non-parametric which assumes no distribution assumptions and it is vigorous when used to both small and large sample sizes.

\subsubsection{Mediation Analysis Multiple Mediator Variable Analysis}

This analysis occurs when exogenous constructs exert their effects in more than one mediating variable (Hair et al., 2017). Since the mediation analysis involves two mediator variables, we observe three indirect effects with two mediator variables (user satisfaction and behavioural intention) (R1, R2 and R3).

In each quality of the e-tax system variable there are three relationships that is R1: (SYSQUAL -> USERSAT $\rightarrow$ BI $->$ TCB $)=(0.319 \times 0.012)+(0.289 \times 0.360)=0.108 ; \mathrm{R} 2($ INFQUAL $\rightarrow$ USERSAT $->$ $\mathrm{BI}->\mathrm{TCB})=(0.185 \times 0.119)+(0.289 \times 0.360)=0.126$; and R3: (SERVQUAL $\rightarrow$ USERSAT $>\mathrm{BI}->$ $\mathrm{TCB})=(0.412 \times 0.118)+(0.289 \times 0.360)=0.151$.

Since all the indirect effects are positive (the relationship pointing in the same direction), their product also is positive. Hence, user satisfaction and behavioural intention denote complementary multiple mediations of the association between information quality, system quality, and service quality on tax compliance behaviour (Figure 2). 


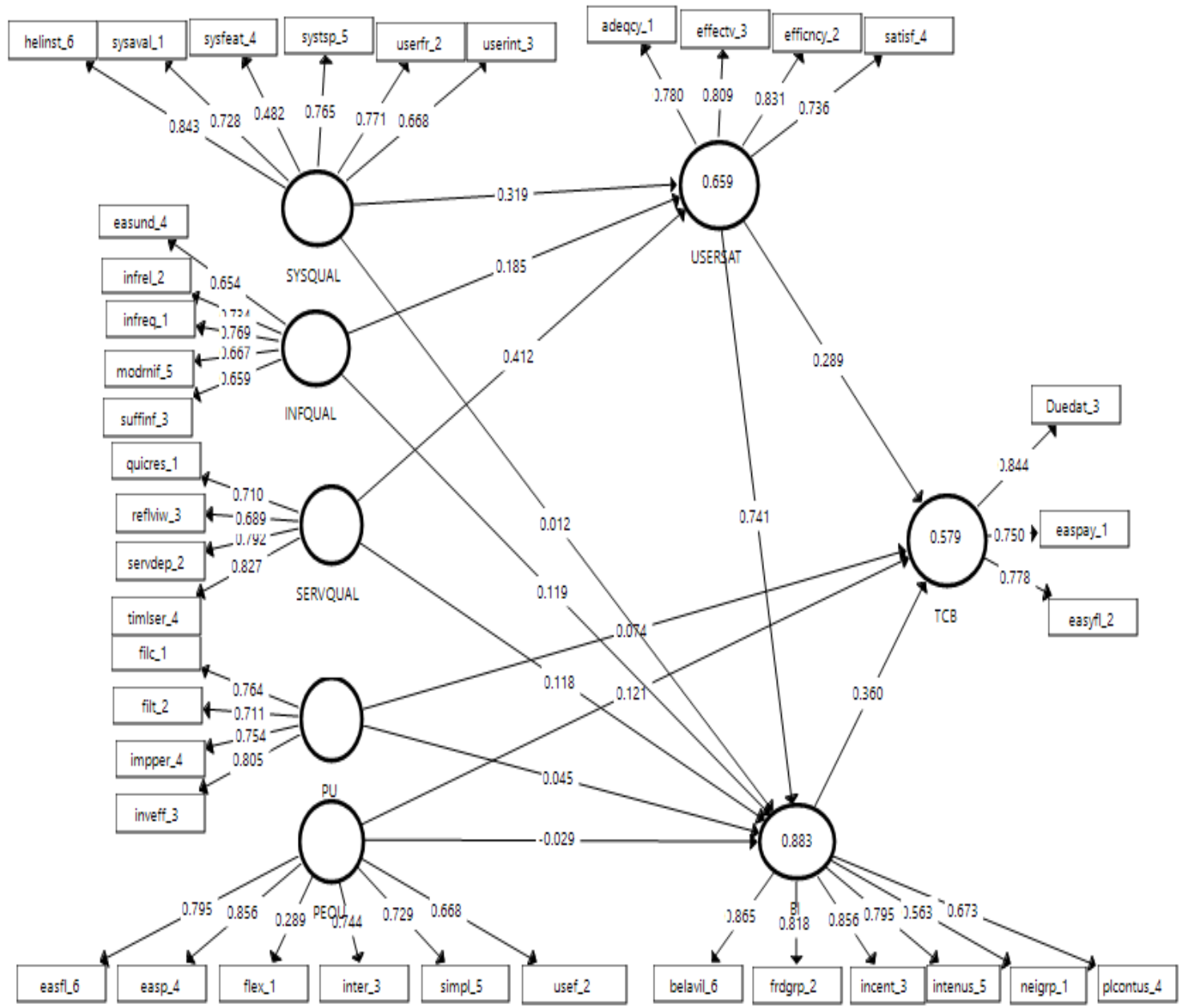

Figure 2. Mediation analysis

\subsubsection{Single Mediator Variable Analysis}

In evaluating single mediator variable analysis, user satisfaction and behavioural intention were tested separately. The findings in Table 1 show that when user satisfaction and behavioural intention is used as mediators separately has a weak role in predicting tax compliance behaviour $(\mathrm{P} \geqslant 0.05)(\mathrm{H} 3 \mathrm{~s}$, $\mathrm{H} 4 \mathrm{~s}$ and H6s not supported). Only information quality and system quality through user satisfaction have a significant effect on tax compliance behaviour. Additionally, behavioural intention mediates only the effect of information quality on tax compliance behaviour.

Table 1. Single mediator analysis

\begin{tabular}{lllllc}
\hline Constructs & $\begin{array}{l}\text { Original } \\
\text { Sample } \\
(\mathrm{O})\end{array}$ & $\begin{array}{l}\text { Sample } \\
\text { Mean (M) }\end{array}$ & $\begin{array}{l}\text { Standard } \\
\text { Deviation } \\
(\text { STDEV })\end{array}$ & $\begin{array}{l}\text { T-Statistics } \\
(|\mathrm{O} / \mathrm{STDEV}|)\end{array}$ & $\begin{array}{l}\text { P- } \\
\text { Values }\end{array}$ \\
\hline INFQUAL -> BI -> TCB & 0.043 & 0.041 & 0.015 & $2 . .809$ & 0.005 \\
SERVQUAL -> BI -> TCB & 0.042 & 0.048 & 0.029 & 1.449 & 0.148 \\
SYSQUAL -> BI -> TCB & 0.004 & 0.004 & 0.014 & 0.298 & 0.766 \\
INFQUAL -> USERSAT -> TCB & 0.053 & 0.051 & 0.026 & 2.059 & 0.040 \\
SERVQUAL -> USERSAT -> TCB & 0.119 & 0.122 & 0.063 & 1.884 & 0.060 \\
SYSQUAL -> USERSAT -> TCB & 0.092 & 0.089 & 0.041 & 2.270 & 0.024 \\
\hline
\end{tabular}


But when both user satisfaction and behavioural intention are used simultaneously (Table 2), the results show that service quality and system quality constructs have a positive significant effect on tax compliance behaviour $(\mathrm{P} \leq 0.05)(\mathrm{H} 1 \mathrm{~m}$ and $\mathrm{H} 2 \mathrm{~m}$ are supported). The findings of this study provide empirical evidence and support for the mediating role of user satisfaction and behavioural intention on the quality of the e-tax system constructs. More precisely, when used simultaneously, user satisfaction and behavioural intention signify a mechanism that underlies the associations between system quality and service quality on tax compliance behaviour.

Table 2. Multiple mediator analysis

\begin{tabular}{cccccc}
\hline Constructs & $\begin{array}{c}\text { Original } \\
\text { Sample (O) }\end{array}$ & $\begin{array}{c}\text { Sample } \\
\text { Mean } \\
(\mathrm{M})\end{array}$ & $\begin{array}{c}\text { Standard } \\
\text { Deviation } \\
\text { (STDEV) }\end{array}$ & $\begin{array}{c}\text { T-Statistics } \\
\text { (O/STDEV) }\end{array}$ & P-Values \\
\hline INFQUAL -> USERSAT -> BI -> TCB & 0.049 & 0.051 & 0.026 & 1.864 & 0.063 \\
SERVQUAL -> USERSAT -> BI -> TCB & 0.110 & 0.108 & 0.036 & 3.079 & 0.002 \\
SYSQUAL -> USERSAT -> BI -> TCB & 0.085 & 0.085 & 0.036 & 2.389 & 0.017 \\
\hline
\end{tabular}

\subsection{Mediation Analysis}

During the interview exercise, taxpayers were asked to provide their responses based on the established qualitative questions. The qualitative analysis envisioned to obtain a comparison of quantitative variables and qualitative themes results that influence tax compliance behaviour. This facilitated to get explanation reasons for significant and insignificant results from the quantitative findings in which quantitative technique could not provide. The theoretically expected symbols for qualitative results using MAXQDA 2020 (inductive approach) from that of Partial Least Square Structural Equation Modeling (PLS-SEM) were indicated. Themes were developed from interviewed respondents on the quality of the e-tax system variables and the attitude towards the e-tax system on tax compliance behaviour.

Table 3. Attitude towards the e-tax system themes generated from the qualitative analysis

\begin{tabular}{|c|c|c|c|c|}
\hline $\mathrm{S} / \mathrm{n}$ & Variables & $\begin{array}{l}\text { Theoretica } \\
\text { lly } \\
\text { expected } \\
\text { symbol }\end{array}$ & $\begin{array}{l}\text { Quantitati } \\
\text { ve } \\
\text { symbol }\end{array}$ & Themes established from qualitative analysis \\
\hline 1 & $\begin{array}{l}\text { Perceived } \\
\text { ease of use } \\
\text { of the e-tax } \\
\text { system }\end{array}$ & $+/-$ & - & $\begin{array}{l}\text { - } \quad \text { Practised users feel the system is easy. } \\
\text { - } \quad \text { The system has the required features. } \\
\text { - } \text { behallenging directorial values dispirit compliance } \\
\text { - Convoluted system procedures. } \\
\text { - Learning instructions are not easy to follow and take } \\
\text { time to learn. }\end{array}$ \\
\hline 2 & $\begin{array}{l}\text { Perceived } \\
\text { usefulness } \\
\text { of the e-tax } \\
\text { system }\end{array}$ & - & $+/-$ & $\begin{array}{l}\text { - The system keeps taxpayers' records. } \\
\text { - Reduced travelling time to the TRA offices. } \\
\text { - The value of a business is monitored. } \\
\text { - Minimizing compliance cost. } \\
\text { - Less involvement in the introduction of the system. } \\
\text { - Uninformed changes on the system. } \\
\text { - The high cost of installing and acquiring the system. } \\
\text { - Does not allow changes on the tax document once } \\
\text { filed }\end{array}$ \\
\hline
\end{tabular}


Three (3) out of six (6) of the interviewed respondents perceived the e-tax system is easy to use and the remaining interviewees claimed that the system has complicated features, is difficult to learn, does not allow to correct the error only allow to preview the tax document and has complicated procedures to follow.

Table 4. Quality of the e-tax system themes generated from the qualitative analysis

\begin{tabular}{|c|c|c|c|c|}
\hline $\mathrm{S} / \mathrm{n}$ & Variables & $\begin{array}{l}\text { Theoretica } \\
\text { lly } \\
\text { expected } \\
\text { symbol }\end{array}$ & $\begin{array}{l}\text { Quantitativ } \\
\text { e symbol }\end{array}$ & Themes developed from qualitative analysis \\
\hline 1 & $\begin{array}{l}\text { Information } \\
\text { quality }\end{array}$ & $+/-$ & + & $\begin{array}{l}\text { - Appropriate information received to some level } \\
\text { - Training on the use of the system } \\
\text { - Feedback is an issue }\end{array}$ \\
\hline 2 & $\begin{array}{l}\text { System } \\
\text { quality }\end{array}$ & $+/-$ & + & $\begin{array}{l}\text { - The system is substantial to some extent. } \\
\text { - } \quad \text { Consistency and power facilities } \\
\text { - Taxpayers involvement in the system } \\
\text { - } \quad \text { Reduced compliance cost }\end{array}$ \\
\hline 3 & $\begin{array}{l}\text { Service } \\
\text { quality }\end{array}$ & + & + & $\begin{array}{l}\text { - Synergetic, feedback, and fast-tracking tax } \\
\text { documents ability. } \\
\text { - Improved performance of the business } \\
\text { - Service is dependable and accurate for our } \\
\text { business } \\
\text { - Cost reduction in using the system }\end{array}$ \\
\hline
\end{tabular}

Three (3) (50\%) of the interviewed respondents claimed that the information and services received from the system are relevant and have the required quality. The remaining three (3) respondents claimed that the information and services received from the system are not germane.

\section{Discussion}

The findings of this study revealed that, since all relationships are positive, then, user satisfaction and behavioural intention mediate the relationship of quality constructs (system quality, information quality and service quality) on tax compliance behaviour. However, user satisfaction and behavioural intention do not provide a significant role in mediating the information quality on tax compliance behaviour. The results support the propositions $(\mathrm{H} 1 \mathrm{~m}, \mathrm{H} 2 \mathrm{~m}$ and $\mathrm{H} 3 \mathrm{~m})$. User satisfaction and behavioural intention have a strong positive effect on tax compliance behaviour (BI $->$ TCB 0.360; $\mathrm{P}=$ 0.006 ) and (USERSAT -> TCB 0.556; 0.001). That is, the behaviour of the person can be influenced by the group in which a person lives or belongs. The acceptance and use of the e-tax system depend on which group the taxpayer has been exposed to. Improved tax compliance behaviour is a result of the positive intention and satisfaction of taxpayers to adopt and use the system.

These results are similar to the previous literature which divulged that accepting and using a certain system is an essential factor of how a person masters and benefits from using that system (self-efficacy) which eventually elicits an intention to use the system (Mandari, Koloseni, \& Nguridada, 2017; Sondakh, 2017; Venkatesh \& Davis, 2000). The relationship of the e-tax system on tax compliance is then reinforced by the ability and understanding of the usage of the system.

Premised in the theoretical outlook, mediation or intervening variable explains the reason for the existence of the associations between antecedent variables and the response variables. The results of this study indicate that both user satisfaction and behavioural intention to use the system partially mediate the relationship between the quality of the e-tax system and attitude of taxpayers towards the e-tax system on tax compliance behaviour (USERSAT $28.9 \%$ and BI $=36.0 \%$ ) respectively. Validating the mediation effect of behavioural intention on tax compliance behaviour was essential to establish the number of effects received by exogenous constructs that are converted into endogenous constructs. 
Previous studies failed to show how user satisfaction and behavioural intention as mediator variables contributed towards tax compliance behaviour (Hamid et al., 2016; Islam, 2012; Mongwaketse, 2015).

User satisfaction and behavioural intention denote a mechanism that underlies the relationship between system quality, service quality, and information quality on tax compliance behaviour. Consistent findings were achieved by Rana et al. (2012) and Ramayasa (2015) who confirmed that the relationships between the quality of the e-tax system on actual behaviour are mediated by user satisfaction and behavioural intention. That is, user satisfaction and behavioural intention are seminal constructs in enhancing the compliance behaviour of the taxpayers. Consequently, Chen et al.(2015) and Hsu et al. (2015) observed that improved service and information from the system (reliable service, consistent and sufficient) improve tax compliance behaviour. User satisfaction and behavioural intention lead to tax compliance behaviour when the system has the required quality. The use of multiple mediations simultaneously in a single model for this study has the advantage to overcome the problem reported by previous studies of failing to obtain the sum of the indirect effects calculated in several simple mediation analysis to reach at the total indirect effects due to the association of mediators in multiple mediations (Zhao et al., 2010). When interviewees were asked the question with regards to user satisfaction and behavioural intention, the following were the response:

The system indeed assisted our business. But more improvement is required in terms of selfassessment, benefits, and productivity, the stability of the internet, cost-efficient in acquiring the system determines the satisfaction which makes easy the exercise of tax payment. Besides, If the environment of using the system supports the users, is reliable, and has the synergetic ability, reduces cost, saves time, and energy makes us comply more and enhances the behavioural intention to use the system.

\section{Conclusions}

This study examined the mediating effects of user satisfaction and behavioural intention on the influence of the quality of the e-tax system on tax compliance behaviour. The results indicated that, when applying a single mediator to test the effect of quality of the e-tax system on tax compliance behaviour, behavioural intention mediates only the relationship between information quality and tax compliance behaviour. Conversely, attitude towards the e-tax system has an insignificant indirect effect on tax compliance behaviour but a positive direct effect. This implies that the relationship between attitude towards the e-tax system and tax compliance behaviour is not mediated by behavioural intention. Besides, when multiple mediators are used (behavioural intention and user satisfaction) the findings divulged that service quality and system quality have significant positive indirect effects on tax compliance behaviour. Henceforth, the effects of the quality of the e-tax system (service quality and system quality) on tax compliance behaviour are mediated by behavioural intention and user satisfaction. The findings of this study provide empirical support for the roles played by mediator variables (user satisfaction and behavioural intention) in influencing the quality of the e-tax system on tax compliance behaviour. When taxpayers are satisfied with the system they use, creates a positive intention towards using the system that eventually reinforces tax compliance behaviour.

This study recommends that the government needs to consider taxpayers' information quality. In measuring the information quality on tax compliance behaviour through user satisfaction and behavioural intention; this study showed that the information is less consistent. Many times, the system can be changed without notification something that discourages taxpayers to comply. To build trust by taxpayers, this study recommends introducing a system that is aligned to the requirements of the users which include the preciseness and completeness of the information received by taxpayers. This study further recommends that taxpayers should be informed and involved during the introduction of the new system. 
This study revealed further that both system quality and service quality are mediated by user satisfaction and behavioural intention when used simultaneously on influencing tax compliance behaviour. However, when user satisfaction and behavioural intention are used separately, has a weak role in influencing tax compliance behaviour. Only behavioural intention mediates the relationship of information quality on tax compliance behaviour. The study recommends that, when the government needs to improve tax compliance behaviour, should consider both taxpayers' satisfaction and their behavioural intention to use the e-tax system. To create tax compliance behaviour, the government is required to ensure that the services provided are of high quality and the system used by taxpayers meets the expectations of the users. The government also is recommended to improve the information that taxpayers receive on the use of the e-tax system. Premised on the findings, information quality has been reported to have a great role in influencing behavioural intention towards using the e-tax system which has a great impact on tax compliance behaviour.

\section{References}

Alabede, J. O., Bt. Zainol Ariffin, Z., \& Idris, K. M. (2011). Public Governance Quality and Tax Compliance Behavior in Nigeria: The Moderating Role of Financial Condition and Risk Preference. Issues In Social And Environmental Accounting, 5(1), 3. https://doi.org/10.22164/isea.v5i1.54

Almutairi, H., \& Subramanian, G. H. (2005). An empirical application of the DeLone and Mclean model in the Kuwaiti private sector. Journal of Computer Information Systems, 45(3), 113-122. https://doi.org/10.1080/08874417.2005.11645849

Ariyanto, R., Rohadi, E., \& Lestari, V. A. (2020). The effect of information quality, system quality, service quality on intention to use and user satisfaction, and their effect on net benefits primary care application at primary health facilities in Malang. IOP Conference Series: Materials Science and Engineering, 732(1). https://doi.org/10.1088/1757-899X/732/1/012084

Baron, R. M., \& Kenny, D. A. (1986). The Moderator-Mediator Variable Distinction in Social Psychological Research. Conceptual, Strategic, and Statistical Considerations. Journal of Personality and Social Psychology, 51(6), 1173-1182. https://doi.org/10.1037/00223514.51.6.1173

Benk, S., Çakmak, A. F., \& Budak, T. (2011). An investigation of tax compliance intention: A theory of planned behaviour approach. 2014 IEEE 17th International Conference on Computational Science and Engineering 2014 IEEE 17th International Conference on Computational Science and Engineering 2014 IEEE 17th International Conference on Computational Science and Engineering User, 28(28), 180-188.

Budu, K. W. A., Yinping, M., \& Mireku, K. K. (2018). Investigating The Effect of Behavioral Intention on E-learning Systems Usage: Empirical Study on Tertiary Education Institutions in Ghana. Mediterranean Journal of Social Sciences, 9(3), 201-216. https://doi.org/10.2478/mjss-2018-0062

Bullock, J. G., Green, D. P., \& Ha, S. E. (2010). Yes, But What's the Mechanism? Journal of Personality and Social Psychology, 98(4), 550-558.

Chen, J. V., Jubilado, R. J. M., Capistrano, E. P. S., \& Yen, D. C. (2015). Factors affecting online tax filing - An application of the IS Success Model and trust theory. Computers in Human Behavior, 43, 251-262. https://doi.org/10.1016/j.chb.2014.11.017 
Davis, F. D., \& Venkatesh, V. (1996). A critical assessment of potential measurement biases in the technology acceptance model: Three experiments. International Journal of Human-Computer Studies, 45(1), 19-45. https://doi.org/10.1006/ijhc.1996.0040

DeLone, W. H., \& McLean, E. R. (2003). The DeLone and McLean model of information systems success: A ten-year update. Journal of Management Information Systems, 19(4), 9-30. https://doi.org/10.1080/07421222.2003.11045748

Esposito Vinzi, V., Chin, W. W., Henseler, J., \& Wang, H. (2010). Handbook of Partial Least Squares: Concepts, Methods and Applications (Springer Handbooks of Computational Statistics). Retrieved from http://www.amazon.com/Handbook-Partial-Least-Squares-Computational/dp/3540328254

Floropoulos, J., Spathis, C., Halvatzis, D., \& Tsipouridou, M. (2010). Measuring the success of the Greek Taxation Information System. International Journal of Information Management 30 (2010) 47-56.The Aristotle University of Thessaloniki, Department of economics, Division of Business Administration, $\quad 54 \quad 124$ Thessaloniki, $\quad$ Greece. $30, \quad 47-56$. https://doi.org/10.1016/j.ijinfomgt.2009.03.013

Gitawaty, D. W. I., Tarbiyah, F. O. F., \& Training, T. (2010). The Correlation Between the Students' Learning Motivation and their Achievement in English ( A Correlational Study in the Eight Class of “MTs Al-Hamidiyah").

Green, J. P., Tonidandel, S., \& Cortina, J. M. (2016). Getting Through the Gate: Statistical and Methodological Issues Raised in the Reviewing Process. In Organizational Research Methods (Vol. 19). https://doi.org/10.1177/1094428116631417

Hair et al., 2017. (2017). A Primer on Partial Least Square Structural Equation Modelling (PLS-SEM). In Journal of Chemical Information and Modeling (Vol. 53). https://doi.org/10.1017/CBO9781107415324.004

Hair, J. F., Risher, J. J., Sarstedt, M., \& Ringle, C. M. (2019). When to use and how to report the results of PLS-SEM. European Business Review, 31(1), 2-24. https://doi.org/10.1108/EBR-11-2018-0203

Hamdollah, R., \& Baghaei, P. (2016). Partial least squares structural equation modelling with R. Practical Assessment, Research and Evaluation, 21(1), 1-16. https://doi.org/10.1108/ebr-10-20130128

Hamid. (2013). Tax Compliance Behaviour of Tax Agents : A Comparative Study of Malaysia and New Zealand.

Hamid, A. A., Razak, F. Z. A., Bakar, A. A., \& Abdullah, W. S. W. (2016). The Effects of Perceived Usefulness and Perceived Ease of Use on Continuance Intention to Use E-Government. Procedia Economics and Finance, 35(October 2015), 644-649. https://doi.org/10.1016/s2212$5671(16) 00079-4$

Hassanzadeh, A., Kanaani, F., \& Elahi, S. (2012). Expert Systems with Applications A model for measuring e-learning systems success in universities. Expert Systems With Applications, 39(12), 10959-10966. https://doi.org/10.1016/j.eswa.2012.03.028

Hayes, A. F., \& Scharkow, M. (2013). The Relative Trustworthiness of Inferential Tests of the Indirect Effect in Statistical Mediation Analysis: Does Method Matter? Psychological Science, 24(10), 1918-1927. https://doi.org/10.1177/0956797613480187

Henseler, I., Falkai, P., \& Gruber, O. (2010). Disturbed functional connectivity within brain networks subserving domain-specific subcomponents of working memory in schizophrenia: Relation to 
performance and clinical symptoms. Journal of Psychiatric Research, 44(6), 364-372. https://doi.org/10.1016/j.jpsychires.2009.09.003

Henseler, J., Dijkstra, T. K., Sarstedt, M., Ringle, C. M., Diamantopoulos, A., Straub, D. W., ... Calantone, R. J. (2014). Common Beliefs and Reality About PLS: Comments on Rönkkö and Evermann (2013). Organizational Research Methods, 17(2), 182-209. https://doi.org/10.1177/1094428114526928

Hsu, P., Yen, H. R., \& Chung, J. (2015). Assessing ERP Post-Implementation Success at the Individual Level: Revisiting the Role of Service Quality. Information \& Management. https://doi.org/10.1016/j.im.2015.06.009

Hyung Chul, L. (2016). Can Electronic Tax Invoicing Improve Tax Compliance? The World Bank Group, (March), 1-58. Retrieved from https://openknowledge.worldbank.org/bitstream/handle/10986/23931/Can0electronic00for0value 0added0tax.pdf? sequence $=1$ \&isAllowed $=\mathrm{y}$

Kassim, E. S., Jailani, S. F. A. K., Hairuddin, H., \& Zamzuri, N. H. (2012). Information System Acceptance and User Satisfaction: The Mediating Role of Trust. Procedia - Social and Behavioral Sciences, 57, 412-418. https://doi.org/10.1016/j.sbspro.2012.09.1205

Kimathi, F. A., \& Zhang, Y. (2019). Citizens' Acceptance of E-Government Service : Examining ETax Filing and Payment System (ETFPS ) in Tanzania. 29(1), 2019.

Kiria, J. S. (2017). Export Processing Zones (EPZs) in Tanzania: Impact and influencing factors. Thesis for the Degree of Doctor of Philosophy in Management. The University of Hull.

Li, Y., Duan, Y., Fu, Z., \& Alford, P. (2012). An empirical study on behavioural intention to reuse elearning systems in rural China. British Journal of Educational Technology, 43(6), 933-948. https://doi.org/10.1111/j.1467-8535.2011.01261.x

MacKinnon, D. P., \& Luecken, L. J. (2008). How and for Whom? Mediation and Moderation in Health Psychology. Health Psychology, 27(2 SUPPL. 2), 99-100. https://doi.org/10.1037/02786133.27.2(Suppl.).S99

Mandari, H., Koloseni, D., \& Nguridada, J. (2017). Electronic Fiscal Device (EFD) Acceptance for Tax Compliance Among Trading Business Community in Tanzania: the Role of Awareness and Trust. International Journal of Economics, Commerce and Management United Kingdom, 3(3), 142-158. Retrieved from http://ijecm.co.uk/

Mathieu, J. E., \& Taylor, S. R. (2006). Erratum: Clarifying conditions and decision points for mediational type inferences in Organizational Behavior. Journal of Organizational Behavior, 27(8), iii-iii. https://doi.org/10.1002/job.426

MD. Aminul Islam, (2012). Factors affecting user satisfaction in the Malaysian income tax e-filing system. African Journal of Business Management, 6(21), 6447-6455. https://doi.org/10.5897/ajbm11.1689

Memon, M. A., Hwa, C. J., Ramayah, T., \& Ting, H. (2018). Mediation Analysis: Issues and Recommendations Journal of Applied Structural Equation Modeling MEDIATION ANALYSIS. (January).

Mohammadi, H. (2015). Computers in Human Behavior Investigating users ' perspectives on elearning: An integration of TAM and IS success model. Computers in Human Behavior, 45, 359374. https://doi.org/10.1016/j.chb.2014.07.044 
Monem, H., Afrasiabi, M., Rezvan, P., \& Dehkordi, S. A. (2013). The Impact of User Quality and Information Quality on the IS Success in Healthcare Context. Journal of Basic and Applied Scientific Research, 3(10), 40-51.

Mongwaketse, P. B. (2015). Perceived effects of an electronic filing system on tax compliance in a district municipality, South Africa. mini-dissertation Submitted in Partial Fulfillment of the Requirements for the Degree Master of Business Administration, (November). https://doi.org/10.1093/cid/cir749

Monica, F. W., \& Makokha, E. N. (2017). Effects of Electronic Tax System on Tax Collection Efficiency in Domestic Taxes Department of Kenya Revenue Authority, Rift Valley Region. European Journal of Business and Management, 9(17), 51-58. https://doi.org/10.1189/jlb.1203638.http

Onwuegbuzie, A.J and Leech, N. L. (2005). On Becoming a Pragmatic Researcher : The Importance of Combining Quantitative and Qualitative Research Methodologies University of South Florida University of Colorado at Denver Paper presented at the annual meeting of the Mid-South Educational Research '.

Pieters, R. (2017). Meaningful mediation analysis: Plausible causal inference and informative communication. Journal of Consumer Research, 44(3), 692-716. https://doi.org/10.1093/jcr/ucx081

Preacher, K. J., \& Hayes, A. F. (2004). SPSS and SAS procedures for estimating indirect effects in simple mediation models KRISTOPHER. Journal of Cellular Physiology, 36(4), 717-731. https://doi.org/10.1002/jcp.28952

Quality, D. (2016). Big Data Quality - Towards an Explanation Model in a Smart City Context.

Rai, A., Lang, S. S., \& Welker, R. B. (2002). Assessing the validity of IS success models: An empirical test and theoretical analysis. Information Systems Research, 13(1), 50-69. https://doi.org/10.1287/isre.13.1.50.96

Ramayasa, I. P. (2015). Evaluation Model of Success and Acceptance of E-Learning. Journal of Theoretical and Applied Information Technology, 3182(3), 462-469. Retrieved from http://www.jatit.org/volumes/Vol82No3/16Vol82No3.pdf

Rana, Williams, Dwivedi, \& Williams. (2012). Theories and Theoretical Models for Examining the Adoption of E-Government Services. E-Service Journal, 8(2), 26. https://doi.org/10.2979/eservicej.8.2.26

Sarstedt, M., Ringle, C. M., Henseler, J., \& Hair, J. F. (2014). On the Emancipation of PLS-SEM: A Commentary on Rigdon (2012). Long Range Planning, 47(3), 154-160. https://doi.org/10.1016/j.lrp.2014.02.007

Saunders, M., Lewis, P., \& Thornhill, A. (2019). Chapter 4: Understanding research philosophy and approaches to theory development. In Research Methods for Business Students.

Sondakh, J. J. (2017). Behavioural intention to use e-tax service system: An application of technology acceptance model. European Research Studies Journal, 20(2), 48-64.

Teddlie, C. (2007). Journal of Mixed Methods Research. https://doi.org/10.1177/2345678906292430

Ting, H. (2018). Convergent validity assessment of formatively measured constructs in PLS-SEM. https://doi.org/10.1108/IJCHM-10-2017-0649 
Tsai, W. H., Chou, Y. W., Leu, J. Der, Chen, D. C., \& Tsaur, T. S. (2015). Investigation of the mediating effects of IT governance-value delivery on service quality and ERP performance. Enterprise Information Systems, 9(2), 139-160. https://doi.org/10.1080/17517575.2013.804952

Umar, M. A., Derashid, C., Ibrahim, I., \& Bidin, Z. (2019). Public governance quality and tax compliance behaviour in developing countries: The mediating role of socioeconomic conditions. International Journal of Social Economics, 46(3), 338-351. https://doi.org/10.1108/IJSE-11-20160338

URT. (2017). Tanzania Revenue Authority. The Fifth Corporate Plan. Convenience, Compliance and Continual improvement.

Venkatesh, V., \& Davis, F. D. (2000). A theoretical extension of the Technology Acceptance Model: Four longitudinal field studies. Management Science, 46(2), 186-204. https://doi.org/10.1287/mnsc.46.2.186.11926

Voorhees, C. M., Brady, M. K., Calantone, R., \& Ramirez, E. (2016). Discriminant validity testing in marketing: an analysis, causes for concern, and proposed remedies. Journal of the Academy of Marketing Science, 44(1), 119-134. https://doi.org/10.1007/s11747-015-0455-4

Wahyudi, F., Respati, H., \& Ardianto, Y. T. (2017). Study on DAPODIK Information System: User Satisfaction as Mediation of System Quality and Information Quality on Net Benefit. Information and Knowledge Management, 7(7), 53-62.

Wisdom, J., \& Creswell, J. W. (2013). Integrating quantitative and qualitative data collection and analysis while studying patient-centred medical home models. Agency for Healthcare Research and Quality, (13-0028-EF), 1-5. https://doi.org/No. 13-0028-EF.

Zhao, X., Lynch, J. G., \& Chen, Q. (2010). Reconsidering Baron and Kenny: Myths and Truths about Mediation Analysis. Journal of Consumer Research, 37(2), 197-206. https://doi.org/10.1086/651257

\section{Appendix}

\section{A.1. Appendix 1: Normality of data for specific variables}

\begin{tabular}{cccccccccc}
\hline & & & & & & & Standard & Excess \\
& No. & Missing & Mean & Median & Min & Max & Deviation & Kurtosis & Skewness \\
\hline case ID & 1 & 0 & 156.681 & 157 & 1 & 313 & 90.014 & -1.195 & -0.003 \\
Sector & 2 & 0 & 1.812 & 2 & 1 & 4 & 0.795 & -0.804 & 0.505 \\
Yrsoper & 3 & 0 & 3.188 & 3 & 1 & 4 & 0.908 & -0.343 & -0.82 \\
Noemplys & 4 & 0 & 3.406 & 4 & 1 & 4 & 0.77 & 0.392 & -1.096 \\
YrsPayTax & 5 & 0 & 3.77 & 4 & 1 & 5 & 0.968 & 0.234 & -0.756 \\
flex_1 & 6 & 0 & 3.77 & 4 & 1 & 7 & 1.516 & -0.538 & -0.269 \\
usef_2 & 7 & 0 & 4.304 & 5 & 1 & 7 & 1.812 & -0.932 & -0.258 \\
inter_3 & 8 & 0 & 4.917 & 5 & 1 & 7 & 1.517 & 0.375 & -0.814 \\
easp_4 & 9 & 0 & 5.118 & 6 & 1 & 7 & 1.711 & -0.019 & -0.884 \\
simpl_5 & 10 & 0 & 5.514 & 6 & 1 & 7 & 1.664 & 0.602 & -1.168 \\
easfl_6 & 11 & 0 & 5.335 & 5 & 1 & 7 & 1.161 & 0.842 & -0.778 \\
filc_1 & 12 & 0 & 4.102 & 4 & 1 & 7 & 1.404 & -0.242 & -0.078 \\
filt_2 & 13 & 0 & 2.994 & 3 & 1 & 7 & 1.623 & -0.504 & 0.538 \\
inveff_3 & 14 & 0 & 3.843 & 4 & 1 & 7 & 1.422 & -0.463 & -0.063 \\
impper_4 & 15 & 0 & 3.032 & 3 & 1 & 7 & 1.441 & -0.473 & 0.221
\end{tabular}




\begin{tabular}{cccccccccc} 
sysaval_1 & 16 & 0 & 3.853 & 4 & 1 & 7 & 1.522 & -0.663 & -0.039 \\
userfr_2 & 17 & 0 & 4.866 & 5 & 1 & 7 & 1.252 & -0.517 & -0.098 \\
userint_3 & 18 & 0 & 4.856 & 5 & 1 & 7 & 1.428 & -0.035 & -0.558 \\
sysfeat_4 & 19 & 0 & 2.808 & 2 & 1 & 7 & 2.015 & -0.979 & 0.66 \\
systsp_5 & 20 & 0 & 4.681 & 5 & 1 & 7 & 1.421 & -0.516 & -0.228 \\
helinst_6 & 21 & 0 & 5.466 & 6 & 2 & 7 & 1.202 & -0.118 & -0.581 \\
infreq_1 & 22 & 0 & 4.463 & 4 & 1 & 7 & 1.328 & -0.246 & -0.221 \\
infrel_2 & 23 & 0 & 4.946 & 5 & 1 & 7 & 1.304 & -0.139 & -0.42 \\
suffinf_3 & 24 & 0 & 4.668 & 5 & 1 & 7 & 1.488 & -0.319 & -0.375 \\
easund_4 & 25 & 0 & 4.805 & 5 & 1 & 7 & 1.409 & -0.119 & -0.457 \\
modrnif_5 & 26 & 0 & 4.863 & 5 & 1 & 7 & 1.388 & -0.257 & -0.444 \\
quicres_1 & 27 & 0 & 5.859 & 6 & 2 & 7 & 0.992 & 0.325 & -0.761 \\
servdep_2 & 28 & 0 & 4.936 & 5 & 1 & 7 & 1.378 & 0.276 & -0.642 \\
reflviw_3 & 29 & 0 & 4.256 & 4 & 1 & 7 & 1.443 & -0.525 & -0.3 \\
timlser_4 & 30 & 0 & 4.939 & 5 & 1 & 7 & 1.45 & -0.036 & -0.64 \\
adeqcy_1 & 31 & 0 & 4.329 & 4 & 1 & 7 & 1.471 & -0.365 & -0.219 \\
efficncy_2 & 32 & 0 & 4.901 & 5 & 1 & 7 & 1.405 & -0.347 & -0.504 \\
effectv_3 & 33 & 0 & 4.767 & 5 & 1 & 7 & 1.521 & -0.51 & -0.4 \\
satisf_4 & 34 & 0 & 4.268 & 4 & 1 & 7 & 1.508 & -0.434 & -0.239 \\
neigrp_1 & 35 & 0 & 4.712 & 5 & 1 & 7 & 1.382 & -0.444 & -0.188 \\
frdgrp_2 & 36 & 0 & 5.927 & 6 & 2 & 7 & 1.007 & 0.224 & -0.758 \\
incent_3 & 37 & 0 & 3.668 & 4 & 1 & 6 & 1.293 & -0.785 & -0.592 \\
plcontus_4 & 38 & 0 & 3.256 & 3 & 1 & 7 & 1.325 & -0.963 & -0.131 \\
intenus_5 & 39 & 0 & 3.805 & 4 & 1 & 6 & 1.25 & -0.545 & -0.701 \\
belavil_6 & 40 & 0 & 2.741 & 3 & 1 & 4 & 1.147 & -1.33 & -0.335 \\
easpay_1 & 41 & 0 & 3.837 & 4 & 1 & 7 & 1.231 & 0.005 & -0.563 \\
easyf1_2 & 42 & 0 & 3.265 & 3 & 1 & 7 & 1.322 & -0.929 & -0.197 \\
Duedat_3 & 43 & 0 & 3.856 & 4 & 1 & 7 & 1.247 & -0.22 & -0.789 \\
\hline
\end{tabular}

\title{
Peran Mediasi Pengaruh Kepuasan Pengguna dan Behavioral Intention Terhadap Pengaruh
}

Sistem Perpajakan Elektronik Terhadap Perilaku Kepatuhan Pajak: Penerapan Teknik

\section{Bootstrap}

\begin{abstract}
Abstrak
Tujuan dari penelitian ini didasarkan pada peran efek mediasi kepuasan pengguna dan niat perilaku pada pengaruh sistem e-pajak pada perilaku kepatuhan pajak. Pendekatan metode campuran (desain penjelasan sekuensial) diterapkan di mana temuan kualitatif digunakan untuk melengkapi hasil dari temuan kuantitatif. Teknik PLS-SEM dengan SmartPLS 3 digunakan untuk menganalisis data secara kuantitatif sedangkan data kualitatif dianalisis menggunakan analisis tematik. Hasil penelitian menunjukkan bahwa niat perilaku hanya memediasi hubungan antara kualitas informasi dan perilaku kepatuhan pajak. Ketika beberapa mediator telah menggunakan temuan mengungkapkan bahwa kualitas layanan dan kualitas sistem memiliki pengaruh tidak langsung positif yang signifikan terhadap perilaku kepatuhan pajak.
\end{abstract}

Kata kunci: sistem e-tax, efek mediasi, perilaku kepatuhan pajak 


\section{Biographies of authors}

Corresponding Author: Faustine Juma Masunga

National Institute of Transport, P.O. BOX 705, Dar es Salaam, Tanzania

Email: faustine.masunga@nit.ac.tz,masungaf@gmail.com, famsunga17@mustudent.ac.tz

PhD student: Mzumbe University, P.O.BOX 1 Morogoro, Tanzania.

Prof. Harun J. Mapesa

Associate Professor

Accounting and Finance Department, Mzumbe University, P.O.BOX 6, Morogoro, Tanzania

Emails: hjmapesa@mzumbe.ac.tz

Dr. Mwakibete Andwilile Nyalle

Accounting and Finance Department, Mzumbe University, P.O.BOX 6, Morogoro, Tanzania

Emails: mwakibete@mzumbe.ac.tz

Dr Joseph Kiria

Lecturer

Mzumbe University, P.O.BOX 6, Morogoro Tanzania.

Email: jkiria@mzumbe.ac.tz

Dr Moshi James

Lecturer

Mzumbe University, P.O.BOX 6, Morogoro, Tanzania

Email: mjames@mzumbe.ac.tz

Dr Jema Myava

Lecturer

Accounting and Finance Department, Mzumbe University, P.O.BOX 6, Morogoro, Tanzania.

Email: jemyava@mzumbe.ac.tz 